\title{
Imposibilidad para la cateterización de la vena gonadal izquierda
}

\author{
Medina Polo J, Villacampa Aubá F. \\ Servicio de Urología. Hospital Universitario 12 de Octubre. Madrid.
}

Actas Urol Esp. 2008;32(9):952

$\mathrm{V}$

Tarón de 24 años de edad que consulta refiriendo molestias y aumento del contenido escrotal izquierdo de años de evolución. Tras la exploración física y la realización de una ecografía-Doppler, es diagnosticado de un varicocele izquierdo grado III/IV, con reflujo espontáneo bajo y de baja resistencia. Se decide embolización percutánea de la vena gonadal izquierda, accediendo a través de la vena iliaca externa derecha. Durante la realización de la flebografía espermática izquierda se visualiza una vena gonadal izquierda con origen ectópico, que tiene su origen en una de las venas intrapiélicas, y además presenta varios bucles (Fig. 1). Todo ello no permite su cateterización para realizar la embolización. Ante la presencia de un origen ectópico de la vena gonadal izquierda, se opta por realizar una varicocelectomía abierta.

Correspondencia autor: Dr. J. Medina Polo

Servicio de Urología. Hospital Universitario 12 de Octubre

Avda. de Córdoba, s/n - 28041 Madrid. Tel.: 913908121

E-mail autor: josemedinapolo@telefonica.net

Información artículo: Imágenes en Urología

Trabajo recibido: abril 2007

Trabajo aceptado: mayo 2007

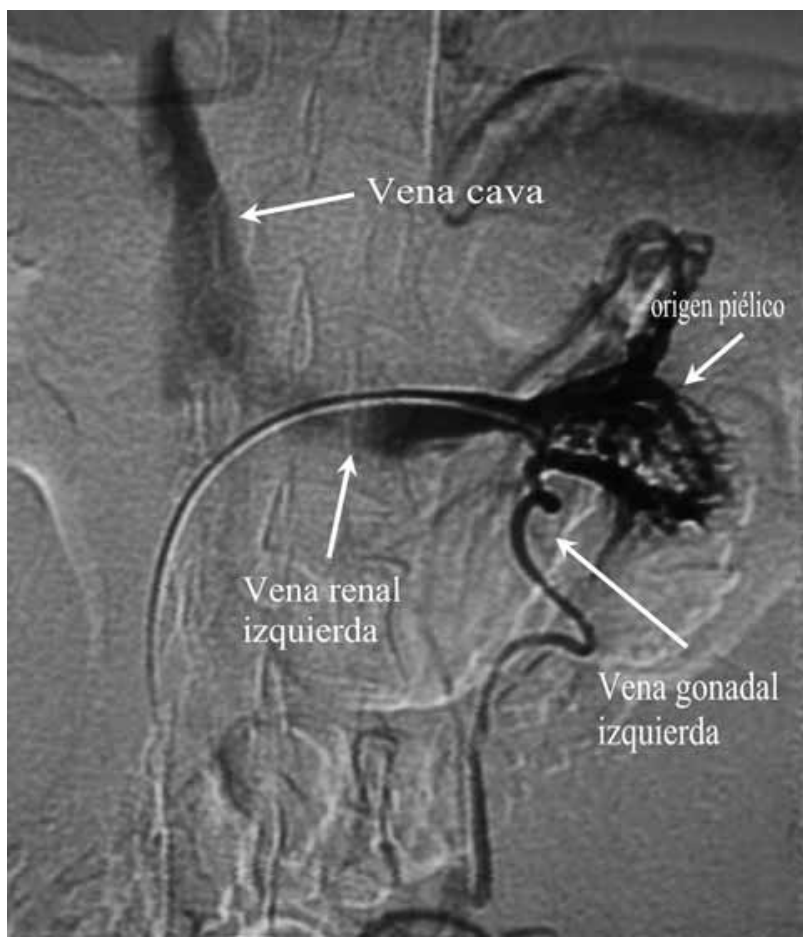

FIGURA 1 